\title{
Perancangan Sistem Monitoring Penyelesaian Berkas Pidana Dengan Metode Rule Based Expert Systems dan Teknologi Radio Frequency Identification
}

\author{
Marfuah* $^{*}$ \\ *Jurusan Sistem Informasi Universitas Universal \\ Naskah Diterima : 19 Juli 2017; Diterima Publikasi : 19 Oktober 2017 \\ DOI : 10.21456/vol7iss2pp146-153
}

\begin{abstract}
The process of criminal cases settlement is based on the regulation of time limit on trial. It is difficult to see the each stage of process because of the number of case files handled. To know the status of settlement, it needs monitoring system of RFID technology built by design to a model of Rule Based Expert Systems. It facilitates the process of data files so it can produce the right, quick and accurate report. The priority of criminal case files is based on the level of completion difficulty while the tracking involves 3 locations: police, public prosecutor and district court. Rule Based Expert System method works following an expert's knowledge in solving a problem. The design that has been made is capable of being implemented and according to the user's needs. It helps to quickly generate the right information of criminal case settling time process.
\end{abstract}

Keywords: Design, Rule Based Expert system; monitoring system; RFID; Criminal Case.

\begin{abstract}
Proses penyelesaian berkas perkara pidana, berjalan berdasarkan batas waktu penahanan yang telah ditentukan berdasarkan aturan, sehingga dengan banyaknya berkas perkara yang ditangani, sulit untuk melihat setiap tahapan proses penyelesaian yang telah dilakukan, untuk mengetahui status penyelesaian berkas perkara perlu dilakukan monitoring sistem menggunakan teknologi Radio Frequency Identification (RFID) yang dibangun dengan perancangan terhadap suatu model Rule Based Expert Systems yang mempermudah pengolahan data penyelesaian berkas perkara pidana sehingga dapat menghasilkan laporan yang tepat, cepat dan akurat mengenai proses waktu penyelesaian, prioritas berkas perkara pidana berdasarkan tingkat kesulitan penyelesaian dan pelacakan berkas perkara pidana yang melibatkan 3 lokasi yaitu kepolisian, jaksa penuntut umum dan pengadilan negeri. Metode Rule Based Expert System berkerja berdasarkan pola pikir seorang pakar dalam menyelesaiakan suatu masalah untuk sistem monitoring penyelesaian berkas perkara pidana. Rancang bangun yang telah dibuat mampu diimplementasikan dan sesuai kebutuhan user membantu secara cepat menghasilkan informasi yang tepat mengenai proses waktu penyelesaian berkas perkara pidana
\end{abstract}

Kata kunci: Rancang Bangun; Rule Based Expert system; Sistem Monitoring; RFID; Criminal Case.

\section{Pendahuluan}

Proses penyelesaian berkas perkara pidana melalui beberapa tahapan, hal ini berkaitan dengan batas waktu penahanan, sehingga perlu dilakukan monitoring waktu penyelesaian berkas perkara pidana (Marbun, 2011). Metode Rule Based Expert Systems digunakan untuk analisis waktu berbasis aturan. Monitoring pelacakan waktu penyelesaian berkas perkara pidana menggunakan teknologi RFID untuk menghasilkan informasi yang lebih akurat mengenai

\footnotetext{
*) Penulis korespondensi : marfuah916@gmail.com
}

waktu proses penyelesaian berkas perkara pidana (Chongwatpol dan Ramesh, 2013).

Implementasi Rule Based Expert Systems untuk sistem monitoring penyelesaian perkara pidana menggunakan teknologi RFID, memberikan kemudahan dalam melakukan monitoring waktu penyelesaian berkas perkara pidana, prioritas berkas perkara berdasarkan tingkat kesulitan penyelesaian perkara pidana dan pelacakan lokasi berkas perkara pidana berdasarkan 3 lokasi yaitu kepolisian, jaksa penuntut umum dan pengadilan negeri. Sehingga meningkatkan kinerja penyelesaian perkara pidana 
secara efektif pada 3 lokasi yang terlibat dalam penyelesaian berkas perkara pidana. Hal ini berhubungan dengan sistem yang mampu memonitoring dan pengendalian secara komplek dengan merespon perubahan secara cepat berdasarkan aturan yang ada pada sistem (Cheng dkk., 1993).

Perancangan sistem monitoring membantu dalam proses pembangunan sistem, sebagai tahap konseptual berdasarkan data yang diperoleh, dilakukan analisis dan model visualisasi proses data menggunakan metode Rule Based Expert Systems dan Teknologi RFID untuk menghasilkan informasi dengan tujuan membangun sistem sesuai kebutuhan user.

\section{Kerangka Teori}

\subsection{Perancangan Basis Data}

Dalam perancangan basis data diperlukan beberapa tahapan-tahapan tertentu untuk melakukan suatu perancangan basis data secara umum yaitu (Ramakrishnan dan Johannes, 2004) :

a. Pengumpulan dan analisis kebutuhan, dari datadata yang ada, dilakukan analisis lebih lanjut sesuai dengan kebutuhan basis data

b. Perancangan konseptual merupakan pengelompokan data menurut kriteria dan hubungan antar kelompok data

c. Perancangan logis, hasil konseptual yang akan diimplementasikan dalam Database Management Systems (DBMS), dan menentukan DBMS

d. Perancangan fisik, implementasi dalam DBMS

Dalam perancangan konseptual menggunakan teknik Entity Relationship Diagram (ERD) yang merupakan bentuk hubungan data yang mengacu pada struktrur dan hubungan antar entitas tempat tersimpannya data. Teknik yang membantu mengidentifikasi hubungan tersebut adalah normalisasi, dengan mengelompokkan elemen-elemen data sehingga menjadi tabel-tabel (Shelly dan Rosenblatt, 2012). Dilakukan dengan menganalisis hubungan berdasarkan primary key dan ketergantungan fungsional antar atribut. Setiap langkah berdasarkan pada bentuk normal sebelumnya dan dalam proses normalisasi hubungan yang terjadi mampu mengurangi anomali penyisipan, penghapusan dan perubahan terhadap informasi yang ada (Kadir, 2009). Mulai dari bentuk tidak normal (Unnormalized Form), First Normal Form (INF) dan Second Normal Form (2NF) untuk lebih jelasnya lihat Gambar 6, diagram analisis functional dependency.

Teknik selanjutnya yaitu Data Flow Diagram (DFD) merupakan suatu bentuk hubungan data dan proses yang lebih menekankan pada fungsi sistem. Teknik ini menggambarkan keluar masuknya data, proses data, dan tempat penyimpanan data. Kemudian masukan dan keluaran dari sistem yang berhubungan dengan entity luar digambarkan menggunakan Context diagram. Untuk proses rancangan DFD level nol yang memberikan gambaran sistem mengenai fungsi, alur data, dan entity luar secara menyeluruh. Langkah selanjutnya menggunakan teknik level diagram yang menguraikan proses dari diagram nol, proses-proses dengan aturan penomoran yang menunjukkan urutan proses untuk mengetahui turunan proses yang ada, misalnya diagram nol dengan penomoran proses 1.0 yang kemudian diuraikan lagi pada proses selanjutnya dengan penomoran 1.1, 1.2 dan seterusnya dan apabila proses 1.1 diuraikan kembali maka penomoran proses 1.1.1, 1.1.2 dan seterusnya dari penomoran tersebut terlihat jelas mengenai turunan proses yang dilakukan dalam level DFD (Shelly dan Rosenblatt, 2012).

Perancangan ERD implementasi rancang bangun Rule Based Expert Systems untuk sistem monitoring penyelesaian perkara pidana menggunakan teknologi RFID, terdiri dari 7 entitas dan masing-masing entitas terdiri dari beberapa atribut sebagaimana ditunjukkan Gambar 6. Kemudian Context diagram, DFD level 1 dan DFD level 0, masing-masing mempunyai 4 entitas dan menggunakan simbol dari Gane and Sarson. Context diagram sebagaimana ditunjukkan Gambar 8, Data Flow Diagram level 0 ditunjukkan Gambar 9 dan Data Flow Diagram level 1 ditunjukkan Gambar 10 .

\subsection{Rule Based Expert Systems}

Menyelesaikan suatu masalah dengan mensimulasikan kerangka pola berpikir seorang pakar (Hartati dan Sari, 2013). Struktur sistem pakar sebagaimana ditunjukkan Gambar 1.

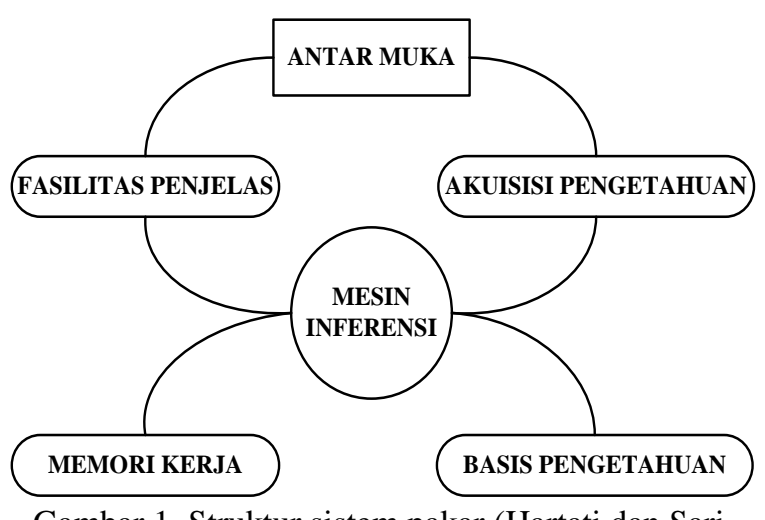

Gambar 1. Struktur sistem pakar (Hartati dan Sari, 2013)

Berdasarkan Gambar 1 antar muka merupakan tempat interaksi pengguna terhadap sistem. Akuisis pengetahuan untuk memperbaharui pengetahuan dalam sistem sesuai dengan perkembangan ruang lingkup permasalahan yang dihadapi. Fasilitas penjelas memberikan penjelesan bagaimana solusi tersebut dihasilkan oleh sistem. Memori kerja menyimpan fakta-fakta terhadap permasalahan. Basis pengetahuan dan mesin inferensi merupakan komponen utama dalam sistem pakar, basis pengetahuan berisi tentang fakta atau aturan-aturan berdasarkan pola pikir seorang pakar. Sedangkan mesin inferensi untuk mencari atau menyesuaikan terhadap aturan-aturan yang digunakan 
sehingga memberikan solusi pendukung pengambilan keputusan. Dengan demikian perancangan sistem melibatkan komponen-komponen tersebut, karena rule dibangun berdasarkan pakar sebagai pengetahuan sistem.

\subsection{Radio Frequency Identification (RFID)}

Teknologi RFID mampu melakukan identifikasi melalui sensor secara serentak dengan berbagai macam objek melalui frekuensi gelombang radio, sensor RFID ada 2 yaitu Reader RFID dan Tag RFID (Li dan Burcin, 2011). Reader, antenna dan tag merupakan 3 komponen RFID. Frekuensi gelombang radio mengambil data pada tag RFID untuk ditransfer kedalam sistem komputer. Sinyal ditransfer oleh antenna melalui gelombang radio kemudian tag mentransmisikan data kembali ke antena (Hanan dkk., 2011). Komponen RFID sebagaimana ditunjukkan Gambar 2.

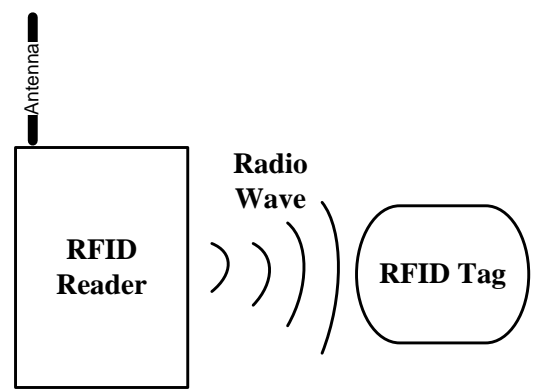

Gambar 2. Komponen RFID (Li dan Burcin, 2011)

Berdasarkan Gambar 2, Reader RFID merupakan penghubung aplikasi sistem komputer terhadap antena pemancar gelombang radio ke tag RFID. Data yang didapat oleh Reader RFID diolah oleh mikrokontroler yang terdapat pada Reader RFID yang bertugas menanggapi perintah dari aplikasi sistem komputer untuk membaca data dari tag RFID (Li dan Burcin, 2011). Tag RFID merupakan suatu rangkaian perangkat elektronik yang terintegrasi dengan antena, terdapat memori untuk menyimpan data (Oztaysi dkk., 2009).

Perancangan sistem monitoring menggunakan teknologi RFID membantu dalam pembacaan data secara cepat dan serentak atau scan berkas perkara dalam suatu ruangan penyimpanan, sehingga tanggal berkas perkara masuk akan dihitung dengan jumlah hari proses berkas perkara untuk melihat berapa lama proses penanganan yang telah berlangsung dan status penanganan yang sedang dilakukan. Sehingga didalam perancangan sistem pada desain file berkas_h dimasukkan atribut RFID yang berisi ID_RFID berdasarkan tag RFID, tag RFID ditempel pada berkas perkara, yang terintegrasi dengan antena pemancar gelombang radio untuk membaca data yang terdapat pada tag RFID.

\subsection{Penyelesaian Perkara Pidana}

Aturan hukum yang mengatur mengenai pelanggaran dan kejahatan yang menimbulkan dampak terhadap sosial disebut dengan hukum pidana (Suharto dan Jonaedi, 2013). Penelitian ini membahas mengenai hukum pidana kejahatan dimana ancaman bukan hanya denda atau kurungan tetapi juga hukuman mati dan penyitaan barang-barang, pencabutan hak dan pengumuman pengadilan.

Adapun rangkaian proses penyelesaian perkara pidana untuk menjatuhkan hukuman terhadap suatu tindak pidana berawal dari adanya sumber perkara yang diselidiki oleh pihak berwenang yang kemudian secara jelas diketahui bahwa tindak pidana tersebut memiliki bukti yang cukup untuk dilakukan penyidikan dan dilanjutkan dengan berita acara pemeriksaan. Seluruh dokumen terkait direkap sehingga menjadi berkas perkara. Setelah berkas perkara dinyatakan lengkap oleh jaksa penuntut umum maka jaksa penuntut umum melimpahkan berkas perkara ke Pengadilan Negeri untuk dilakukan persidangan yang akan menghasilkan putusan dari hakim yang berwenang (Suharto dan Jonaedi, 2013).

\section{Metode}

Adapun langkah-langkah penelitian yang harus dilalui dalam penelitian sebagaimana ditunjukkan Gambar 3.

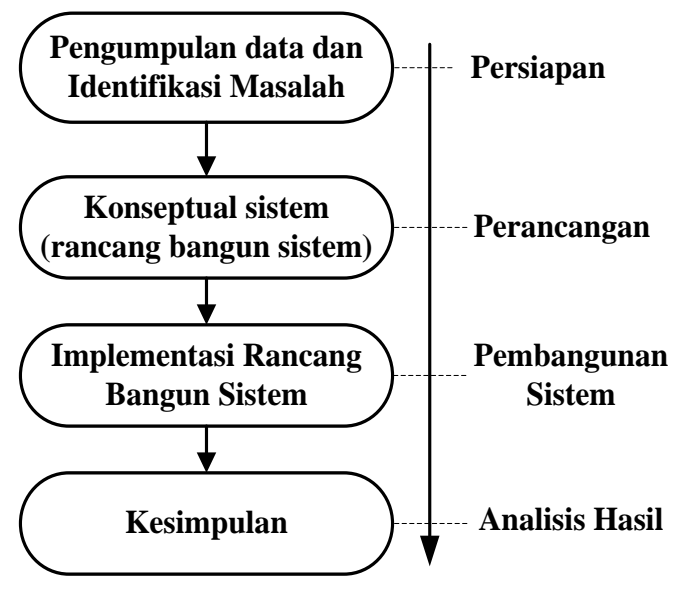

Gambar 3. Prosedur penelitian

Berdasarkan Gambar 3, dijelaskan sebagai berikut:

1. Tahap persiapan

Beberapa hal yang dilakukan dalam tahap persiapan adalah melakukan pengumpulan datadata yang dibutuhkan dalam proses penyelesaian berkas perkara seperti data tersangka, data perkara dan informasi pakar mengenai rule yang terkait dengan proses penyelesaian berkas perkara pidana, serta literatur, jurnal, artikel, situs internet, buku dan karya-karya ilmiah mengenai implementasi rancang bangun Rule Based Expert Systems untuk sistem monitoring penyelesaian perkara pidana 
menggunakan teknologi RFID. Kemudian melakukan identifikasi masalah dalam sistem monitoring penyelesaian perkara pidana menggunakan metode Rule Based Expert Systems dengan teknologi RFID.

2. Tahap perancangan

Berdasarkan data-data yang diperoleh kemudian melakukan proses rancang bangun untuk diimplementasikan kedalam sistem. Normalisasi merupakan proses identififkasi kebutuhan user berdasarkan data-data yang ada untuk menghindari terjadinya redudansi data dan memodelkan sistem untuk menghasilkan informasi yang tepat, cepat dan akurat mengenai proses penyelesaian perkara pidana. Proses awal normalisasi terhadap Unnormalized Form, data yang diperoleh kemudian dibentuk dalam First Normal Form (INF) untuk melengkapi data dengan satu nilai data tunggal pada satu sel tabel atau menghilangkan adanya repeating groups. Selanjutnya proses Second Normal Form (2NF) yang mengidentifikasi candidate untuk primary key.

4. Pembangunan sistem

Implementasi rancang bangun Rule Based Expert Systems untuk sistem monitoring penyelesaian perkara pidana menggunakan teknologi RFID, dibangun dalam bentuk aplikasi komputer sesuai dengan pola rancang bangun sistem. Berdasarkan pada perancangan basis data, dari tahapan normalisasi kemudian penggambaran ERD, Context diagram dan DFD dalam menerapkan Rule Based Expert Systems untuk sistem monitoring penyelesaian perkara pidana menggunakan teknologi RFID. Kemudian diimplementasikan dalam suatu sistem komputer. Sistem tersebut mempunyai 4 form input, 3 proses dan 4 output. Menu utama sistem sebagaimana ditunjukkan Gambar 4.

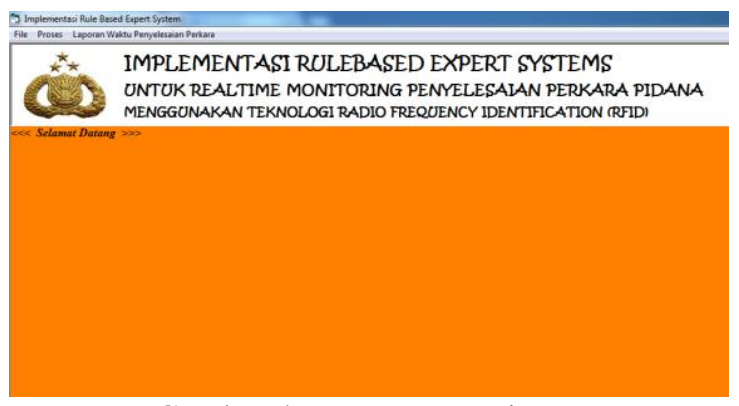

Gambar 4. Menu utama sistem

Berikut merupakan form pelimpahan berkas perkara pidana, yang berelasi dengan tabel berkas_h dan konklusi_h, sebagaimana ditunjukkan Gambar 5.

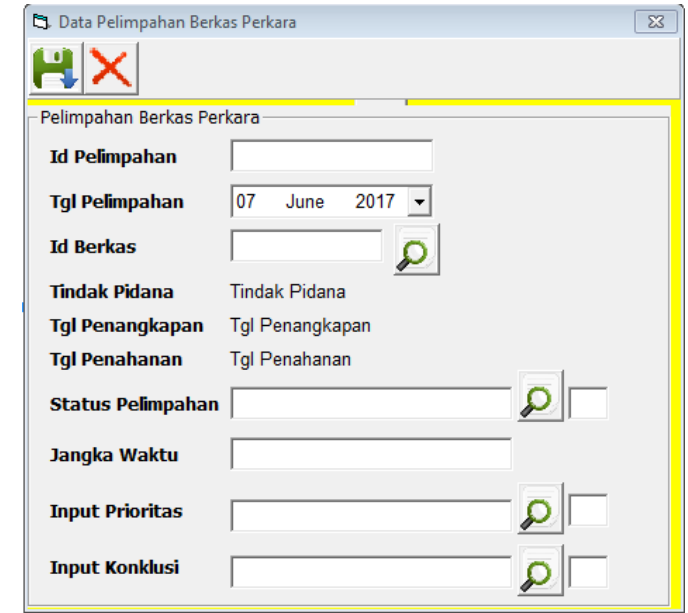

Gambar 5. Form pelimpahan berkas perkara pidana

5. Tahap analisis hasil

Berdasarkan pada simulasi proses implementasi rancang bangun sistem monitoring menggunakan metode Rule Based Expert Systems dan teknologi RFID untuk penyelesaian perkara pidana terhadap perancangan konseptual yang dimodelkan berdasarkan hasil analisis digunakan untuk memperoleh kesimpulan hasil penelitian.

\section{Hasil dan Pembahasan}

Rancang bangun Rule Based Expert Systems untuk sistem monitoring penyelesaian perkara pidana menggunakan teknologi RFID. Dengan melakukan analisis data sesuai dengan kebutuhan dalam membuat pola rancangan sistem penyelesaian berkas perkara pidana untuk menghasilakan prioritas berkas perkara yang membantu pihak kepolisian dalam pengambilan keputusan untuk memprioritaskan penanganan perkara pidana serta langkah apa yang harus dilakukan selanjutnya, status keberadaaan berkas perkara dan status proses berkas perkara dengan sistem monitoring, memberikan informasi waktu berjalannya proses penyelesaian berkas perkara pidana yang ditangani dengan menggunakan teknologi RFID.

Status lokasi berkas perkara diketahui dengan adanya pelimpahan berkas perkara pidana yang terdeteksi dengan teknologi RFID. Dengan demikian informasi secara transparan diketahui oleh masyarakat mengenai proses penanganan berkas perkara pidana. Selain itu diharapkan mampu meningkatkan kinerja pihak Kepolisian, Jaksa Penuntut Umum dan Hakim Pengadilan Negeri dalam menangani proses berkas perkara pidana. Untuk mempermudah proses tersebut dalam perancangan sistem dilakukan identifikasi dependency. Diagram analisis functional dependency sebagaimana ditunjukkan Gambar 6. 


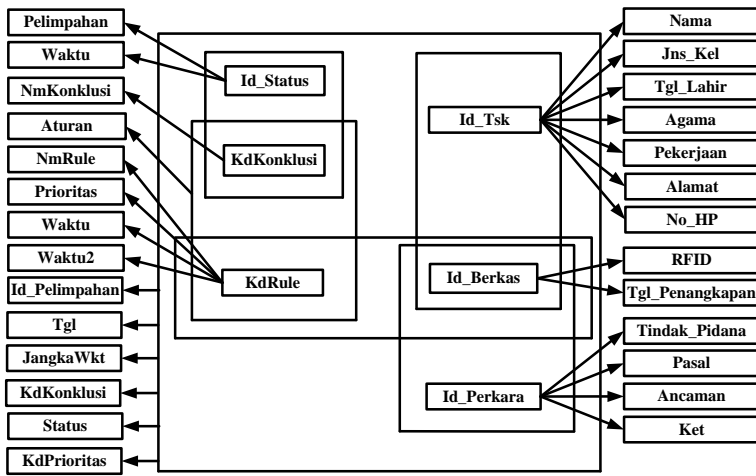

Gambar 6. Diagram analisis functional dependency

Berdasarkan Gambar 6 analisis functional dependency menghasilkan beberapa tabel. Tabel-tabel tersebut adalah:

1. Tabel-tabel master

a. Tabel tersangka.

Desain file tersangka dipergunakan untuk menyimpan data diri pelaku tindak pidana. Tabel ini mempunyai hubungan many to many terhadap tabel fakta berkas_h sehingga menghasilkan suatu relasi berkas_d. Desain file ms_tersangka sebagaimana ditunjukkan pada Tabel 1.

Tabel 1. Desain file ms_tersangka

\begin{tabular}{|c|c|c|c|}
\hline Field & Type Data & $\begin{array}{c}\text { Field } \\
\text { Size }\end{array}$ & Keterangan \\
\hline Id_Tsk & Varchar & 5 & ID tersangka \\
\hline Nama & Varchar & 55 & $\begin{array}{l}\text { Nama lengkap } \\
\text { tersangka }\end{array}$ \\
\hline Jns_Kel & Varchar & 1 & $\begin{array}{l}\text { Jenis kelamin }(\mathrm{L} / \mathrm{P}) \\
\text { tersangka }\end{array}$ \\
\hline Tgl_Lahir & Date & & $\begin{array}{l}\text { Tanggal, bulan dan } \\
\text { tahun lahir tersangka }\end{array}$ \\
\hline Agama & Varchar & 15 & $\begin{array}{l}\text { Agama yang dianut } \\
\text { tersangka }\end{array}$ \\
\hline Pekerjaan & Varchar & 20 & Pekerjaan tersangka \\
\hline Alamat & Varchar & 100 & Alamat tersangka \\
\hline No_HP & Varchar & 12 & $\begin{array}{l}\text { Nomor handphone } \\
\text { tersangka }\end{array}$ \\
\hline
\end{tabular}

b. Tabel perkara

Tabel 2 desain file perkara dipergunakan untuk menyimpan data-data atau daftar perkara tindak pidana, sehingga mempermudah sistem untuk melakukan laporan daftar perkara. Tabel ini memiliki relasi many to many terhadap tabel fakta berkas_h dengan kerelasian berkas_perkara. Desain file ms_perkara sebagaimana ditunjukkan pada Tabel 2 .

c. Tabel rule penyelesaian perkara pidana

Tabel 3 desain file rule digunakan untuk menyimpan data-data atau daftar aturan-aturan (rule) dalam penyelesaian perkara pidana, tabel ini mempunyai relasi many to many terhadap tabel konklusi_h sehingga menciptakan relasi konklusi_d. Desain file ms_rule sebagaimana ditunjukkan pada Tabel 3.
Tabel 2. Desain file ms_perkara

\begin{tabular}{|c|c|c|c|}
\hline Field & Type Data & $\begin{array}{c}\text { Field } \\
\text { Size }\end{array}$ & Keterangan \\
\hline Id_Perkara & Varchar & 5 & $\begin{array}{l}\text { ID Perkara } \\
\text { Pidana }\end{array}$ \\
\hline Tindak_Pidana & Varchar & 35 & Tindak pidana \\
\hline Pasal & Varchar & 10 & $\begin{array}{l}\text { Pasal tindak } \\
\text { pidana }\end{array}$ \\
\hline Ancaman & Varchar & 50 & $\begin{array}{l}\text { Ancaman } \\
\text { hukuman } \\
\text { pidana }\end{array}$ \\
\hline Ket & Varchar & 50 & $\begin{array}{l}\text { Keterangan } \\
\text { tindak pidana }\end{array}$ \\
\hline
\end{tabular}

Tabel 3. Desain file ms_rule

\begin{tabular}{cccl}
\hline Field & $\begin{array}{c}\text { Type } \\
\text { Data }\end{array}$ & Field Size & \multicolumn{1}{c}{ Keterangan } \\
\hline KdRule & Varchar & 4 & Kode rule \\
NmRule & Varchar & 200 & $\begin{array}{l}\text { Nama rule } \\
1=\text { Rule } \text { prioritas } \\
0=\text { Bukan rule } \\
\text { prioritas }\end{array}$ \\
Prioritas & Integer & 1 & Waktu minimal \\
Waktu & Integer & 3 & Waktu maksimal \\
Waktu2 & Integer & 3 & \\
\hline
\end{tabular}

d. Tabel ms_status

Tabel 4 desain file status dipergunakan untuk menyimpan daftar status pelimpahan perkara pidana. Tabel ini mempunyai relasi one to many terhadap tabel fakta konklusi_h dengan keterangan status lokasi. Desain file status sebagaimana ditunjukkan pada Tabel 4.

Tabel 4. Desain file status

\begin{tabular}{|c|c|c|c|}
\hline Field & $\begin{array}{l}\text { Type } \\
\text { Data }\end{array}$ & Field Size & Keterangan \\
\hline Id_Status & Integer & 1 & $\begin{array}{l}\text { Id status } \\
\text { pelimpahan } \\
\text { perkara }\end{array}$ \\
\hline Pelimpahan & Varchar & 30 & $\begin{array}{l}\text { Status lokasi } \\
\text { pelimpahan : } \\
\text { 1. Kepolisian } \\
\text { 2. Jaksa } \\
\text { Penuntut } \\
\text { Umum }\end{array}$ \\
\hline & & & $\begin{array}{l}\text { 3. Pengadilan } \\
\text { Negeri } \\
\text { 4. Admin }\end{array}$ \\
\hline Waktu & Integer & 3 & $\begin{array}{l}\text { Jangka waktu } \\
\text { Kepolisian } \\
\text { 120, JPU } 124 \\
\text { \& PN } 150\end{array}$ \\
\hline
\end{tabular}

2. Tabel-tabel fakta

a. Tabel berkas

Tabel 5 desain file berkas_h merupakan tabel untuk menyimpan data berkas perkara. Tabel ini mempunyai relasi dari konklusi_d. Desain file berkas_h sebagaimana ditunjukkan pada Tabel 5. 
Tabel 5. Desain file berkas_h

\begin{tabular}{|c|c|c|c|}
\hline Field & Type Data & Field Size & Keterangan \\
\hline Id_Berkas & Varchar & 5 & $\begin{array}{l}\text { ID berkas } \\
\text { perkara }\end{array}$ \\
\hline RFID & Varchar & 15 & ID RFID \\
\hline $\begin{array}{l}\text { Tgl_Penangka } \\
\text { pan }\end{array}$ & Datetime & & $\begin{array}{l}\text { Tanggal dan } \\
\text { waktu } \\
\text { penangkapan } \\
\text { Id status }\end{array}$ \\
\hline Status & Varchar & 20 & $\begin{array}{l}\text { lokasi berkas } \\
\text { perkara }\end{array}$ \\
\hline
\end{tabular}

b. Tabel detail berkas tindak pidana

Tabel 6 desain file berkas_d merupakan tabel untuk menyimpan data berkas perkara dan tersangka yang mempunyai relasi many to many. Desain file berkas_d sebagaimana ditunjukkan pada Tabel 6 .

Tabel 6. Desain file berkas_d

\begin{tabular}{lccl}
\hline \multicolumn{1}{c}{ Field } & Type & Field & \multicolumn{1}{c}{ Keterangan } \\
& Data & Size & \multicolumn{1}{c}{ ID berkas perkara } \\
Id_Berkas & Varchar & 5 & ID tersangka tindak \\
Id_Tsk & Varchar & 5 & $\begin{array}{l}\text { ID } \\
\text { pidana }\end{array}$ \\
\hline
\end{tabular}

c. Tabel detail berkas tindak pidana

Tabel 7 desain file berkas_d merupakan tabel untuk menyimpan data berkas perkara dan tersangka yang mempunyai relasi many to many. Desain file berkas_rule sebagaimana ditunjukkan pada Tabel 7 .

Tabel 7. Desain file berkas_rule

\begin{tabular}{lccl}
\hline \multicolumn{1}{c}{ Field } & $\begin{array}{c}\text { Type } \\
\text { Data }\end{array}$ & $\begin{array}{c}\text { Field } \\
\text { Size }\end{array}$ & \multicolumn{1}{c}{ Keterangan } \\
\hline Id_Berkas & Varchar & 5 & ID berkas perkara \\
KdRule & Char & 5 & $\begin{array}{l}\text { ID tersangka tindak pidana } \\
\text { Aturan logika yang } \\
\text { digunakan yaitu And }=0 \\
\text { dan Or = 1 }\end{array}$ \\
\hline
\end{tabular}

d. Tabel berkas_perkara tindak pidana

Tabel 8 desain file berkas_perkara merupakan tabel untuk menyimpan data perkara dan berkas yang mempunyai relasi many to many. Desain file berkas_perkara sebagaimana ditunjukkan pada Tabel 8 .

Tabel 8. Desain file berkas_perkara

\begin{tabular}{cccl}
\hline \multirow{2}{*}{ Field } & $\begin{array}{c}\text { Type } \\
\text { Data }\end{array}$ & $\begin{array}{c}\text { Field } \\
\text { Size }\end{array}$ & \multicolumn{1}{c}{ Keterangan } \\
\hline Id_Berkas & Varchar & 5 & ID berkas perkara \\
Id_Perkara & Varchar & 5 & ID perkara \\
\hline
\end{tabular}

e. Tabel konklusi penyelesaian perkara pidana

Tabel 9 desain file konklusi_h untuk menyimpan daftar konklusi atau hasil kesimpulan dari rule dalam penyelesaian perkara pidana. Tabel ini mempunyai relasi many to many terhadap rule sehingga menciptakan relasi konklusi_d. serta tabel ini mempunyai relasi dari tabel status. Desain file konklusi_h sebagaimana ditunjukkan pada Tabel 9.

Tabel 9. Desain file konklusi_h.

\begin{tabular}{cccl}
\hline \multicolumn{1}{c}{ Field } & $\begin{array}{c}\text { Type } \\
\text { Data }\end{array}$ & $\begin{array}{c}\text { Field } \\
\text { Size }\end{array}$ & \multicolumn{1}{c}{ Keterangan } \\
\hline KdKonklusi & Char & 1 & $\begin{array}{l}\text { Kode konklusi dari } \\
\text { aturan }\end{array}$ \\
NmKonklusi & Varchar & 200 & Nama konklusi \\
Id_Status & Integer & 1 & Id status lokasi rule \\
\hline
\end{tabular}

f. Tabel detail konklusi penyelesaian perkara pidana

Tabel 10 desain file konklusi_d untuk menyimpan daftar konklusi atau hasil kesimpulan dari rule dalam penyelesaian perkara pidana. Tabel ini berelasi many to many terhadap tabel pelimpahan dan berkas_h. Desain file konklusi_d sebagaimana ditunjukkan pada Tabel 10.

Tabel 10. Desain file konklusi_d

\begin{tabular}{|c|c|c|c|}
\hline Field & $\begin{array}{l}\text { Type } \\
\text { Data }\end{array}$ & $\begin{array}{c}\text { Field } \\
\text { Size }\end{array}$ & Keterangan \\
\hline IdKonklusi & Char & 5 & $\begin{array}{l}\text { Id kesimpulan dari } \\
\text { aturan }\end{array}$ \\
\hline KdRule & Char & 5 & Kesimpulan dari aturan \\
\hline Aturan & Integer & 1 & $\begin{array}{l}\text { Aturan logika yang } \\
\text { digunakan yaitu And = } \\
0 \text { dan Or }=1\end{array}$ \\
\hline
\end{tabular}

g. Tabel pelimpahan

Tabel 11 desain file pelimpahan yang menyimpan data-data pelimpahan berkas perkara untuk melakukan proses perhitungan batas waktu penyelesaian berkas perkara, status proses dan status lokasi berkas perkara, tabel ini mempunyai relasi dari tabel konklusi_d, berkas_h serta status. Desain file pelimpahan sebagaimana ditunjukkan pada Tabel 11 .

Tabel 11. Desain file pelimpahan

\begin{tabular}{|c|c|c|c|}
\hline Field & Type Data & $\begin{array}{c}\text { Field } \\
\text { Size }\end{array}$ & Keterangan \\
\hline Id_Pelimpahan & Varchar & 5 & $\begin{array}{l}\text { ID pelimpahan } \\
\text { berkas perkara }\end{array}$ \\
\hline Tgl_Pelimpahan & Datetime & & $\begin{array}{l}\text { Tanggal } \\
\text { pelimpahan } \\
\text { berkas }\end{array}$ \\
\hline Id_Berkas & Varchar & 5 & $\begin{array}{l}\text { ID berkas } \\
\text { perkara } \\
\text { Jangka waktu : } \\
\text { Kepolisian } 120\end{array}$ \\
\hline JangkaWkt & Integer & 3 & $\begin{array}{l}\text { hari } \\
\text { JPU } 124 \text { hari } \\
\text { PN } 150 \text { hari } \\
\text { Status lokasi : }\end{array}$ \\
\hline Status & Integer & 1 & $\begin{array}{l}1: \text { Kepolisian, } 2 \\
: \text { JPU } \\
3: \text { PN }\end{array}$ \\
\hline KdKonklusi & Varchar & 5 & $\begin{array}{l}\text { Status proses } \\
\text { berkas perkara }\end{array}$ \\
\hline KdPrioritas & Integer & 5 & $\begin{array}{l}\text { Status prioritas } \\
\text { perkara }\end{array}$ \\
\hline
\end{tabular}


Dengan demikian perlu adanya pembentukan relasi terhadap entitas dan atribut yang terlibat, alur sistem serta proses-proses dalam sistem, untuk mempermudah hal tersebut dibuatlah sebuah rancangan ERD, Context diagram dan DFD. Entity Relationship Diagram sebagaimana ditunjukkan Gambar 7.

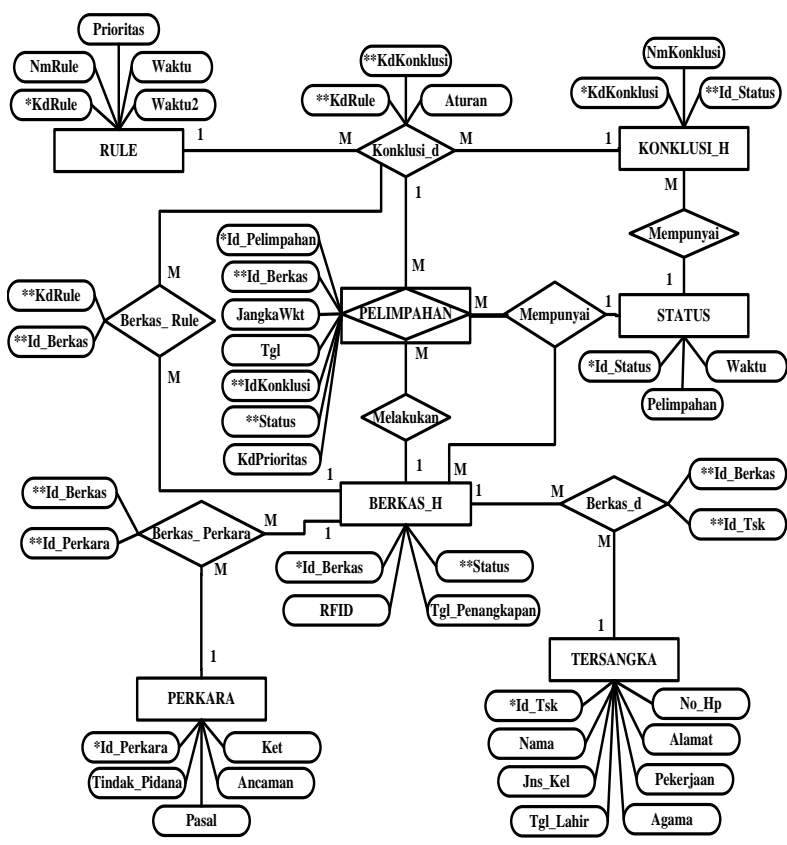

Gambar 7. Entity Relationship Diagram penyelesaian perkara pidana menggunakan Teknologi Radio Frequency Identification (RFID)

Berdasarkan pada Gambar 7 menggambarkan bagaimana relasi yang ada pada implementasi Rulebase Expert Systems untuk sistem monitoring penyelesaian perkara pidana menggunakan teknologi RFID. Ada 7 entity yang terlibat yaitu entity rule, entity konklusi_h, entity pelimpahan, entity status, entity berkas_h, entity perkara dan entity tersangka. Berdasarkan pada 7 entity tersebut maka terbentuk 7 relasi.

Setelah hubungan atau relasi tabel jelas maka selanjutnya menggambarkan penyimpanan data dan proses dengan Data Flow Diagram (DFD), yang menunjukkan hubungan antara data pada sistem dan proses pada sistem. Namun terlebih dahulu digambarkan dalam bentuk Context diagram untuk memperjelas input dan output sistem mengenai datadata atau informasi-informasi apa saja yang masuk dan keluar dalam suatu sistem dari tiap komponen. Context diagram sebagaimana ditunjukkan Gambar 8.

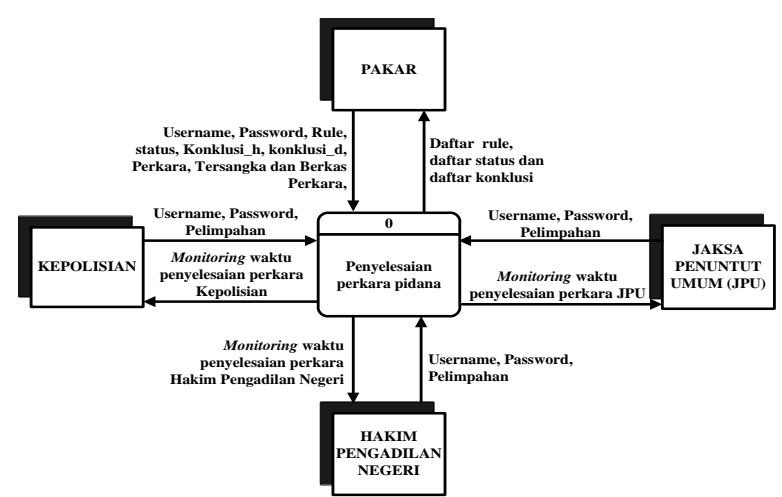

Gambar 8. Context diagram penyelesaian perkara pidana menggunakan Teknologi Radio Frequency Identification (RFID)

Selanjutnya untuk menggambarkan arus sistem yang saling berhubungan agar lebih mudah dikomunikasikan dengan bentuk DFD. Data Flow Diagram level 0 sebagaimana ditunjukkan Gambar 9.

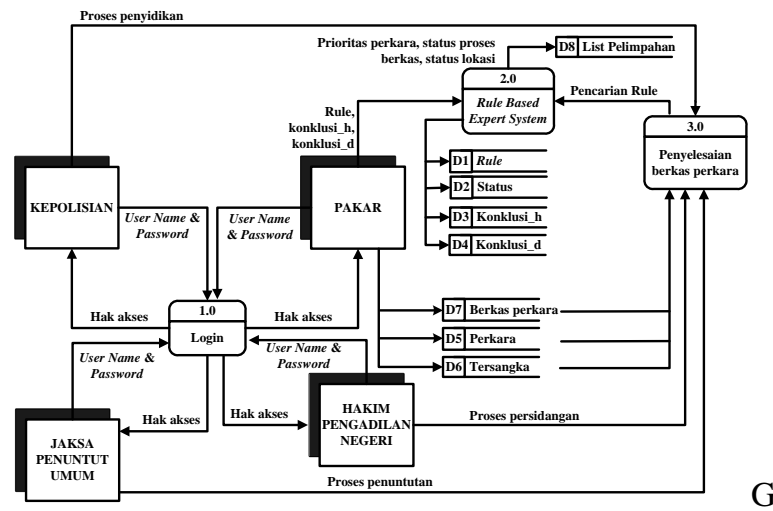

ambar 9. Data Flow Diagram level 0 penyelesaian perkara menggunakan Teknologi Radio Frequency Identification (RFID)

Untuk lebih memperjelas mengenai input, proses dan output yang ada, maka berdasarkan pada DFD level 0 , proses-proses tersebut dapat diturunkan lagi menjadi lebih rinci, terhadap setiap proses yang ada mulai dari proses 2.0 dan 3.0. Data Flow Diagram level 1 sebagaimana ditunjukkan Gambar 10.

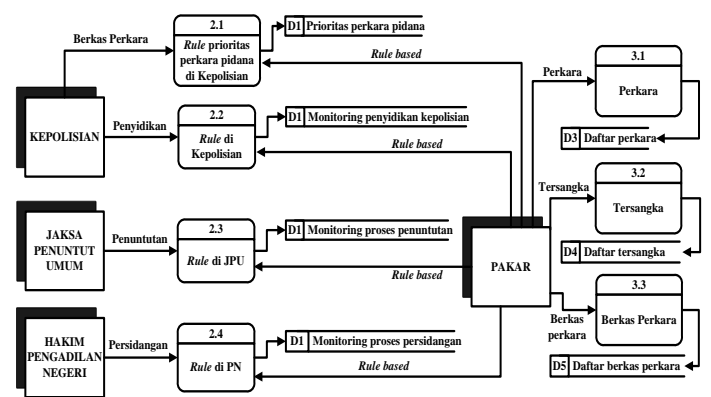

Gambar 10. Data Flow Diagram level 1 penyelesaian perkara pidana menggunakan Teknologi Radio Frequency Identification (RFID) 


\section{Kesimpulan}

Rancang bangun sistem monitoring penyelesaian berkas perkara pidana menggunakan metode Rule Based Expert Systems dan teknologi RFID mampu diimplementasikan dalam pembangunan sistem monitoring untuk mempermudah pengolahan data, sehingga memberikan informasi secara tepat, cepat dan akurat mengenai proses waktu penyelesaian, prioritas berkas perkara pidana berdasarkan tingkat kesulitan penyelesaian dan pelacakan berkas perkara pidana yang melibatkan 3 lokasi yaitu kepolisian, jaksa penuntut umum dan pengadilan negeri.

Perancangan sistem monitoring penyelesaian berkas perkara pidana ini, untuk kedepannya dapat diperluas hingga banding ke Pengadilan Tinggi dan Mahkamah Agung. Mengingat adanya kemungkinan proses tingkat banding untuk perkara-perkara yang penting atau prioritas.

\section{Daftar Pustaka}

Cheng, A.M.K., Browne, J.C., Mok, A.K., dan Wang, R.H., 1993. Analysis of Realtime Rule Based Systemss with Behavioral Constraint Assertions Specified in Estella, IEEE Transactions on Software Engineering, vol. 19, 863-885.

Chongwatpol, J., dan Ramesh, S., 2013. RFID Enabled Track And Traceability in Job Shop Scheduling Environment, European Journal of Operational Research 227, 453-463.
Hanan, M.A., Maher, A., R.A. Begum., dan Hassan, B., 2011. Radio Frequency Identification (RFID) and Communication Technologies For Solid Waste Bin and Truck Monitoring Systems, Waste Management 31, 2406-2413.

Hartati, S., dan Sari, I., 2013. Sistem Pakar dan Pengembangannya, Graha Ilmu Yogyakarta.

Kadir, A., 2009, Dasar Perancangan dan Implementasi Database Relasional, Andi Yogyakarta.

Li, N., dan Burcin, B.G., 2011. Performance Based Evaluation of RFID Based Indoor Location Sensing Solutions For The Built Environment, Advanced Engineering Informatics 25, 535-546.

Marbun, R., 2011. Kiat Jitu Menyelesaikan Kasus Hukum, Visimedia Jakarta.

Oztaysi, B., Serdar, B., dan Farma, A., 2009. Radio Frequency Identification (RFID) in Hospitality, Technovation 29, 618-624.

Ramakrishnan, R., dan Johannes, G., 2004. Sistem Manajemen Database Edisi 3 Internasional, Indonesia Andi and McGraw Hill Education.

Shelly, G.B., dan Rosenblatt, H.J., 2012. Analysis and Design for Systemss $9^{\text {th }}$ Edition International, Cengage Learning International Office, Australia.

Suharto., dan Jonaedi, E., 2013. Panduan Praktis Bila Anda Menghadapai Perkara Pidana Mulai Proses Penyelidikan Hingga Persidangan, Kencana Prenadamedia Group Jakarta. 